\title{
Vertical distributions of chlorophyll in deep, warm monomictic lakes
}

David P. Hamilton ${ }^{1,}$, Katherine R. O’Brien ${ }^{2}$, Michele A. Burford ${ }^{3}$, Justin D. Brookes ${ }^{4}$ and Chris G. McBride ${ }^{1}$

${ }^{1}$ Centre for Biodiversity and Ecology Research, University of Waikato, Hamilton 3240, New Zealand

${ }^{2}$ Division of Environmental Engineering, University of Queensland, St Lucia 4072, Australia

${ }^{3}$ Australian Rivers Institute, Griffith University, Nathan 4111, Queensland, Australia

${ }^{4}$ Water Research Cluster, University of Adelaide, Adelaide 5005, South Australia, Australia

*Corresponding author: e-mail: davidh@waikato.ac.nz, phone: +64 7858 5046, facsimile: +6478384324

Abbreviated title: Chlorophyll distributions in deep lakes 
Abstract. The factors affecting vertical distributions of chlorophyll fluorescence were examined in four temperate, warm monomictic lakes. Each of the lakes (max. depth $>$ $80 \mathrm{~m}$ ) were sampled over two years at intervals from monthly to seasonal. Profiles were taken of chlorophyll fluorescence (as a proxy for algal biomass), temperature and irradiance, as well as integrated samples from the surface mixed layer for chlorophyll $a(\operatorname{chl} a)$ and nutrient concentrations in each lake. Depth profiles of chlorophyll fluorescence were also made along transects of the longest axis of each lake. Chlorophyll fluorescence maxima occurred at depths closely correlated with euphotic depth $\left(\mathrm{r}^{2}=0.67, \mathrm{p}<0.01\right)$, which varied with nutrient status of the lakes. Whilst seasonal thermal density stratification is a prerequisite for the existence of a deep chlorophyll fluorescence maximum (DCM), our study provides evidence that the depth of light penetration largely dictates the DCM depth during stratification. Reduction in water clarity through eutrophication can cause a shift in phytoplankton distributions from a DCM in spring or summer to a surface chlorophyll maximum within the surface mixed layer when the depth of the euphotic zone $\left(\mathrm{z}_{\mathrm{eu}}\right)$ is consistently shallower than the depth of the surface mixed layer $\left(\mathrm{z}_{\mathrm{SML}}\right)$. Trophic status has a key role in determining vertical distributions of chlorophyll in the four lakes, but does not appear to disrupt the annual cycle of maximum chlorophyll in winter.

Key words. Phytoplankton; deep chlorophyll maximum; Rotorua lakes; fluorescence; non-photochemical quenching. 


\section{Introduction}

In deep waterbodies with high transparency, phytoplankton distributions may be skewed away from the surface, resulting in formation of a deep chlorophyll maximum (DCM) at intermediate depths across density discontinuities and at relatively low light levels (e.g., MacIntyre et al., 1995; Condie, 1999; Huisman et al., 2006). The phytoplankton constituting DCMs include non-motile diatoms (Abbott et al., 1984; Davey and Heaney, 1989), buoyancy-regulating cyanobacteria (Walsby and Schanz, 2002) or flagellates (Clegg et al., 2007), as well as species that co-exist using different depth strata (Larson et al., 1987). Natural aggregations of non-motile particles including diatom cells at density discontinuities suggest a physical mechanism for DCM formation (MacIntyre et al., 1995; Condie, 1999), but DCMs can also be induced physiologically from an increase in cellular chlorophyll concentration (Steele, 1964; Fennel and Boss, 2003).

Fee (1976) indicates that water clarity is the overarching driver of the formation and depth of DCMs but vertical nutrient distributions may also be important (Abbott et al., 1984), and DCMs can themselves play an important role in intercepting upward fluxes of nutrients (Letelier et al., 2004). It has also been suggested that plunging river inflows that insert into the metalimion may provide nutrients necessary to sustain or stimulate DCMs (Wurtsbaugh et al., 2001).

Abbott et al. (1984) identified three different 'regimes' during the seasonal occurrence of a DCM in Lake Tahoe, with transitions alternately controlled by diffusion, nutrient supply and light. In temperate lakes, seasonal changes in mixing produce a seasonal reset of chlorophyll distributions that complicates the interpretation of the DCM formation and ablation as a regime shift (sensu Carpenter, 2003; Bayley et al., 2007). By contrast, the DCM tends to be deeper and persistent 
throughout most or all of the year in subtropical oceans (Letelier et al., 2004). For the subset of temperate lakes that are warm monomictic, the prolonged period of seasonal stratification could provide sufficient time for DCM populations to approach an equilibrium state with the prevailing environmental conditions (Fee, 1976), thereby allowing vertical chlorophyll distributions to be used to interpret variations in water transparency and mixing depths amongst lakes or across different years within a lake.

The paradigm of spring blooms or an annual maximum of phytoplankton biomass in spring in deep temperate lakes has been pervasive, yet many exceptions have been demonstrated including evidence of greater seasonality of chlorophyll $a$ with increasing trophic status (Marshall and Peters, 1989). Vincent (1983) found that in deep, oligotrophic Lake Taupo, New Zealand, depth-integrated phytoplankton biomass was nearly ten-fold higher in winter than in summer, with a similar ratio of production between these seasons. Vincent et al. (1984a) similarly found that the annual autumn-winter biomass maximum in mesotrophic Lake Rotoiti, located near Lake Taupo, occurred when there was maximum phytoplankton productivity. By contrast, Fee (1976) found that seasonal disruption of the DCM and redistribution of the elevated levels of hypolimnetic biomass were responsible for a 'bloom' that coincided with autumnal mixing in lakes of Northwestern Ontario.

In this study, four deep, warm monomictic lakes were selected to test relationships between the seasonal depth of the DCM and mixing and light penetration depths, as well as nutrient availability in surface waters. Our objective was to identify the predominant environmental factors that influence the variability of DCMs in both time and space. We identify up to four different vertical distributions of chlorophyll fluorescence in each lake that depend on seasonal mixing depths and light penetration, as well as nutrient concentrations. A further objective of our work 
was to test the wider generality of the winter maximum of depth integrated chlorophyll noted previously in two of the lakes; Taupo (Vincent, 1983) and Rotoiti (Vincent et al., 1984a), with the addition of two other lakes of comparable depth subject to similar climate.

\section{Methods}

\section{Study sites}

The four deep lakes of this study are in the Central Volcanic Plateau of North Island, New Zealand, and were formed up to $140,000 \mathrm{yr}$ B.P. by volcanic activity. Relevant morphological variables for each of the lakes are given in Table 1. Lakes Taupo, Rotoma and Tarawera have low summer mean chlorophyll $a$ (chl $a$ ) while values for Lake Rotoiti are relatively high (Table 1), but all are monomictic with winter mixing from late June to early September. The natural seasonal succession of phytoplankton in the four lakes has been documented by Cassie (1978), Vincent (1983), Vincent et al. (1984a) and Ryan et al. (2006). Diatoms are dominant in winter and spring, while cyanobacteria, chlorophytes and chrysophytes become increasingly abundant in summer and autumn in each of the lakes. Subsurface populations include diatoms (e.g. Aulacoseira spp., Fragilaria spp. and Asterionella spp.; Cassie, 1978), notably at the DCM in Lake Tarawera (Ryan et al., 2006), while Botryococcus sometimes coexists with Aulacoseira granulata in sub-surface samples in Lake Rotoma (Cassie, 1978).

\section{Sampling methods and analysis}

Sampling was carried out monthly in each lake at a central station, from 2003 to 2006, as part of a routine water quality monitoring programme. Water column profiles of temperature were taken with a Sea Bird Electronics 19plus SEACAT Profiler (CTD; 
Sea-Bird Electronics Inc., Washington) with additional mounted sensors for downwelling broadband photosynthetically available radiation $\left[\mathrm{E}_{\mathrm{d}}(\mathrm{PAR})\right]$ (Licor Inc.) and chlorophyll fluorescence (Chelsea Instruments Ltd). Transects of chlorophyll fluorescence (Dr. Haardt Optik Mikroelektronik miniBackScat I) were also taken periodically in each lake with a BioFish (ADM-Elektronik, Germany) linked to a GPS reference and water depth (Garmin GPSMAP 168 Sounding). Stored BioFish data were processed with Ocean Data View software to interpolate fluorescence data into isopleths over the transect distance and water depth.

Surface water samples were taken at the central station in each lake with an integrated tube. Known volumes of sample water were syringe-filtered $(0.45 \mu \mathrm{m}$ $\mathrm{GF} / \mathrm{C}$ filters) and filters and water samples were placed on ice in the dark before freezing on return to the laboratory. Nutrients were analysed on thawed samples with a Lachat QuickChem ${ }^{\circledR}$ Flow Injection Analyzer (FIA+ 8000 Series, Zellweger Analytics, Inc.) for ammonium $\left(\mathrm{NH}_{4}-\mathrm{N}\right)$, soluble reactive phosphorus $\left(\mathrm{PO}_{4}-\mathrm{P}\right)$ and oxidized nitrogen species $\left(\mathrm{NO}_{3}-\mathrm{N}\right.$ and $\left.\mathrm{NO}_{2}-\mathrm{N} ; \mathrm{NO}_{\mathrm{X}}-\mathrm{N}\right)$ (Lachat QuickChem ${ }^{\circledR}$ Methods 10-107-06-2-C, 10-115-01-1-A and 10-107-04-1-A, respectively). Concentrations of $\mathrm{NO}_{3}-\mathrm{N}$ were determined by subtracting $\mathrm{NO}_{2}-\mathrm{N}$ from $\mathrm{NO}_{\mathrm{X}}-\mathrm{N}$. Chlorophyll a concentrations were determined spectrofluorometrically following thawing of filters and pigment extraction in $90 \%$ acetone. Samples were acidified to correct for phaeopigments (Arar and Collins, 1992). The depth of surface-integrated samples varied between the lakes $(10 \mathrm{~m}$ in Lake Taupo and $17 \mathrm{~m}$ in the other three lakes) due to differences in the routine monitoring programme designed for the lakes. There was no significant difference $(\mathrm{p}>0.05)$ between the values of chlorophyll, DRP, $\mathrm{NH}_{4}$ and $\mathrm{NO}_{3}$ measured at $10 \mathrm{~m}$ and those measured at $20 \mathrm{~m}$ in Lake Taupo, 
hence the $17 \mathrm{~m}$ depth-integrated samples in Lake Taupo were used for comparisons with the $10 \mathrm{~m}$ depth-integrated samples in the other lakes.

\section{Data analysis}

Thermocline, metalimnion, chlorophyll fluorescence maximum and euphotic depths ( $1 \%$ of surface irradiance) were determined from CTD casts. At each site, the exact depth of the CTD cast varied due to changes in lake water levels, small differences in boat position and operator practice. For consistency of analysis, all profiles were truncated to the minimum observed depths at each site: $95 \mathrm{~m}$ for lakes Taupo and Rotoiti, and $75 \mathrm{~m}$ for lakes Rotoma and Tarawera.

The depth of the thermocline and metalimnion was determined from the temperature $(\mathrm{T})$ gradient, $\mathrm{dT} / \mathrm{dz}$ where $\mathrm{z}$ is water depth defined positive downward. Data were smoothed to ensure that the thermocline was defined by a coherent gradient. Smoothing was done with Matlab ${ }^{\mathrm{TM}}$ using a locally weighted running average method with $2 \mathrm{~m}$ span. The thermocline was then defined as the depth where the value of $d T / d z$ was a minimum (i.e., the density $(\rho)$ gradient, $d \rho / d z$, was maximal), the top of the metalimnion as the depth where $\mathrm{dT} / \mathrm{dz}$ was initially $<-0.225$ ${ }^{\circ} \mathrm{C} \mathrm{m}^{-1}$ and the bottom as the maximum depth with $\mathrm{dT} / \mathrm{dz}>-0.225{ }^{\circ} \mathrm{C} \mathrm{m}^{-1}$, based on a critical gradient value comparable to Sherman et al. (1998). If $\mathrm{dT} / \mathrm{dz}$ was $>-0.225{ }^{\circ} \mathrm{C}$ $\mathrm{m}^{-1}$ throughout the profile, the water column was assumed to be fully mixed and the thermocline depth was set to the maximum depth. The top $5 \mathrm{~m}$ of the profile were not included in the thermocline analysis to avoid diurnal thermoclines (Spigel and Imberger 1987).

Noise in chlorophyll fluorescence profiles was removed with the same Matlab $^{\mathrm{TM}}$ smoothing technique used for temperature profiles, with a smoothing span 
of $6 \mathrm{~m}$. This length was then used sequentially in rolling intervals through the profile to fit a polynomial equation over the depth.

With exposure of phytoplankton to excess light energy, there may be a decrease in fluorescence quantum yield due mostly to non-photochemical quenching (NPQ), which complicates the direct use of in vivo fluorescence measurements as a proxy for pigment concentrations (Fennel and Boss, 2003). Biofish fluorescence transects in Lake Taupo were of sufficient duration to provide evidence of diurnal occurrence of NPQ in surface waters, but without taking profiles at night (e.g., Sackmann et al., 2008) we had no quantitative mechanism for eliminating NPQ from fluorescence profiles. Diurnal stratification, resulting in varying histories of light exposure for phytoplankton in surface waters (cf. Vincent et al., 1984b), also meant that we could not relate NPQ occurrence directly to surface light for selected time intervals. The effect of NPQ on depth-averaged fluorescence was assessed by comparing averaged vertical fluorescence profiles with different surface depths removed; the top $2 \mathrm{~m}$ of fluorescence data were used as the average value obtained was not significantly different $(\mathrm{p}<0.05, \mathrm{n}=10$ in Lake Taupo to $\mathrm{n}=23$ in Lake Rotoiti) from that obtained using a cut off at greater depths in each of the four lakes.

Each fluorescence profile was categorised into one of four patterns. The Surface Mixed Layer occurred when the water column was stratified and fluorescence values over at least $75 \%$ of the thickness of the epilimnion were greater than $75 \%$ of the maximum chlorophyll fluorescence in the profile. It was located either in the epilimnion or in the top $4 \mathrm{~m}$ of the metalimnion. The Bottom Layer occurred when average chlorophyll fluorescence in bottom $15 \mathrm{~m}$ of the profile was at least $50 \%$ higher than the average chlorophyll fluorescence in the top $15 \mathrm{~m}$. The Chlorophyll Fluorescence Maximum distribution corresponded to a distinct peak in fluorescence 
(F) that was at least 50\% higher than the depth-averaged value, the water column was stratified, and the profile did not fulfil the criteria for either the Surface Mixed Layer or Bottom Layer. Any profiles that did not satisfy the above criteria were allocated to a Uniform distribution. Visual inspection of profiles was used to confirm that these criteria successfully differentiated the patterns.

The vertical attenuation coefficient for broadband photosynthetically available radiation $(400-700 \mathrm{~nm}),\left[\mathrm{K}_{d}(\mathrm{PAR})\right]$, was calculated from the slope of $-\ln \left[\mathrm{E}_{\mathrm{d}}(\mathrm{PAR})\right]$ versus depth regressions within a depth range truncated arbitrarily from the surface up to $7 \mathrm{~m}$ to avoid surface noise and at the bottom to where the value of $E_{d}(P A R)$ was approximately $1 \%$ of the subsurface value. Thus the euphotic depth $\left(\mathrm{z}_{\mathrm{eu}}\right)$, was estimated to $\pm 1 \mathrm{~m}$. At the depth of the chlorophyll fluorescence maximum, $\mathrm{z}_{\mathrm{Fmax}}$, the percentage of surface irradiance $\left(\%_{\mathrm{Fmax}}\right)$ was calculated as:

$$
\%_{\mathrm{F} \max }=100 \frac{\mathrm{E}(0) \mathrm{e}^{-\mathrm{K}_{\mathrm{d}} \mathrm{z}_{\mathrm{F} \text { ax }}}}{\mathrm{E}\left(\mathrm{z}_{\mathrm{F} \text { max }}\right)}
$$

Concentrations of nutrients and chl $a$ were compared among depths within each lake using a paired t-test. There was no significant difference $(p>0.05)$ between concentrations of chlorophyll $a, \mathrm{PO}_{4}-\mathrm{P}, \mathrm{NH}_{4}-\mathrm{N}$ and $\mathrm{NO}_{3}-\mathrm{N}$ at depths of 10 and $20 \mathrm{~m}$ in Lake Taupo so we included measurements from the $10 \mathrm{~m}$ integrated tube sample in for comparisons with those from the $17 \mathrm{~m}$ integrated tube samples in the other lakes. Solvent-extracted chl $a$ from water samples at $15 \mathrm{~m}$ depth at four sites in Lake Taupo over a 6-month period was strongly correlated with chlorophyll fluorescence at 14-16 $\mathrm{m}$ depth $\left(\mathrm{r}^{2}=0.91, \mathrm{n}=20\right)$. This relationship and frequent calibration of in vivo fluorescence to extracted $\operatorname{chl} a$ were used to approximate chl $a$ from fluorescence for each lake and date. 


\section{Results}

Biofish data for a representative summer transect from each lake show marked variations of chlorophyll fluorescence with depth, but relatively uniform fluorescence horizontally except in Lake Rotoiti (Fig. 2). The distance represented by the horizontal axis of the Biofish transects in figure 2 also reflects a temporal component associated with the c. 1-5 hr transect duration. For example, in Lake Taupo surface chlorophyll fluorescence decreased by c. $50 \%$ between the pre-dawn commencement and midday completion of a transect in January 2005, due mostly to NPQ (Fig. 2a). A distinct deep chlorophyll fluorescence maximum (DCM) is evident as a relatively contiguous band of elevated fluorescence in lakes Rotoma, Tarawera and Taupo, well below where there was NPQ. In Lake Taupo, the DCM was located between depths of approximately 40 and $50 \mathrm{~m}$. Similarly the DCM spans the entire transect, though it is less contiguous, at a depth c. $35 \mathrm{~m}$ in Lake Rotoma, and $25 \mathrm{~m}$ in Lake Tarawera, with a less distinctive DCM at the lake boundaries than in the central basin. By contrast, there is no evidence of a DCM in Lake Rotoiti where there was very high surface fluorescence and strong horizontal gradients (Fig. 2d).

At the seasonal time scale vertical fluorescence profiles reveal a wide variety of distributions and a range of metalimnion and euphotic depths (Fig. 3). At least one sampling date for each lake coincided with a period of water column mixing in winter, between June and August. Variations in epilimnion depth within individual lakes were greater than variations in euphotic depth. Whilst the euphotic depth was initially within the metalimnion during the stratified period in Lake Taupo (March and April 2006), the epilimnion had deepened to $5 \mathrm{~m}$ below the euphotic depth by June 2006, near the end of the stratified period. Similarly in Lake Rotoma, the euphotic depth was just within the lower limit of the metalimnion in January 2006, but by June 2006 
the euphotic depth was nearly $20 \mathrm{~m}$ above the upper limit of the metalimnion. In Lake Rotoiti, the euphotic depth was within the epilimnion $\left(\mathrm{z}_{\mathrm{eu}}<\mathrm{z}_{\mathrm{SML}}\right)$ for the two sampling occasions when the water column was stratified (January and April 2006), while in Lake Tarawera, the euphotic depth was within or immediately above the metalimnion during the stratified period.

Chlorophyll fluorescence maxima were evident in the near-surface layer, at mid-depths and near the bottom of the water column, at different times in the four lakes (Fig. 3). On the basis of examination of individual Biofish transects and fluorescence profiles, we consider that NPQ was unlikely to occur at depths greater than one-half of the euphotic depth (i.e., depths where $\mathrm{E}(\mathrm{z})<0.1 \mathrm{E}(0))$. With this stipulation, a DCM could be clearly resolved as a sub-surface peak in March and April 2006 in Lake Taupo, January 2006 in Lake Rotoma, and November 2003 in Lake Tarawera, but there was no evidence of a DCM in Lake Rotoiti. There was a shift from a clearly defined peak to a uniform distribution of chlorophyll fluorescence in the epilimnion in all lakes in autumn/winter, with deepening of the epilimnion (June 2006 in Lakes Taupo and Rotoma, April 2004 in Lake Tarawera, and April 2006 in Lake Rotoiti). Fluorescence profiles generally varied little with depth during winter mixing, as noted in profiles in July 2006 in lakes Taupo and Rotoma, August 2004 in Lake Tarawera, and June 2006 in Lake Rotoiti, though there was occasionally still some evidence of NPQ (e.g., Lake Rotoma in July 2006). Some unusual fluorescence distributions occurred in winter or early spring when there was increasing water column fluorescence with depth extending well below the euphotic zone (e.g., Lake Rotoma in September 2006); these distributions did not fit our conventional classification of a DCM. A comparison of chl $a$ fluorescence across the four lakes was made for winter profiles that were relatively constant with depth; 
values were equivalent to $3-5 \mu \mathrm{g} \mathrm{L}^{-1}$ in lakes Taupo, Rotoma and Rotoiti, but considerably higher $\left(\sim 25 \mu \mathrm{g} \mathrm{L}{ }^{-1}\right)$ in Lake Rotoiti.

Peaks in chlorophyll fluorescence occurred within or immediately below the metalimnion in lakes Taupo, Rotoma and Tarawera, and in the surface mixed layer of Lake Rotoiti, based on discrete profile data normalized by the depth-averaged fluorescence. The normalized chlorophyll fluorescence profiles, as well as the associated metalimnion and euphotic depth data, were averaged for each of the allocated distribution patterns (Surface Mixed Layer, Uniform, Bottom Layer and Chlorophyll Fluorescence Maximum) for each lake (Fig. 4). In all cases, the Chlorophyll Fluorescence Maximum depth occurs at approximately the euphotic depth. For the Bottom Layer profiles the sub-surface peak of fluorescence extends well beyond the depth of NPQ. The Uniform pattern occurs in all four lakes but the criterion for the Bottom Layer pattern is satisfied in our data only in lakes Rotoiti and Rotoma.

Observations of the four fluorescence distributions for each of the four lakes are summarized for each month of the year in Table 2. In all lakes, the Chlorophyll Fluorescence Maximum was observed for at least five months during summerautumn. Lakes Tarawera and Rotoiti also showed evidence of this pattern in spring. The Chlorophyll Fluorescence Maximum was followed by the Surface Mixed Layer pattern in autumn/winter, which was characterized by an increase in both the thickness of the epilimnion and chlorophyll fluorescence. The Uniform pattern typically occurred during overturn in all lakes, but was most prolonged in lakes Tarawera and Rotoiti. The Bottom Layer pattern followed the Uniform pattern only in lakes Rotoiti and Lake Rotoma in spring. It was not observed in lakes Taupo or 
Tarawera, possibly due in Lake Taupo to an absence of measurements from August to November.

The depth-averaged fluorescence generally increased with increasing thermocline depth in all lakes, and was usually highest at winter turnover (Fig. 5). The annual maximum in depth-integrated $\operatorname{chl} a$ (as measured by in vivo fluorescence) was highest in Lake Rotoiti $\left(>50 \mu \mathrm{g} \mathrm{L}^{-1}\right)$ and lowest in Lake Taupo $\left(<5 \mu \mathrm{g} \mathrm{L}^{-1}\right)$. For each lake there appeared to be a trough in depth-averaged fluorescence around January to February of each year and a progressive increase in fluorescence through autumn preceding a rapid increase around overturn (i.e., when thermocline depth equated to the maximum lake depth; Fig. 5).

The average depth of the chlorophyll fluorescence maximum during stratified periods was greatest in Lake Taupo followed by Rotoma, Tarawera and then Rotoiti (Fig. 6a). The same sequence was observed for euphotic depth (Fig. 6b), and this variable explained $67 \%$ of variation $(p<0.01)$ in the depth of the chlorophyll fluorescence maximum over the whole dataset (Fig. 7a). By contrast, the thickness of the epilimnion was not significantly different $(p>0.05)$ between the lakes (Fig. 6c), nor was it related significantly $(\mathrm{p}>0.05)$ to the depth of the chlorophyll fluorescence maximum $\left(R^{2}=0.16\right.$, Fig. $\left.7 b\right)$ or the euphotic depth $\left(R^{2}=0.10\right.$, Fig. $\left.7 c\right)$.

In stratified conditions the chlorophyll fluorescence maximum always occurred below the epilimnion, indicating a DCM, in lakes Taupo and Rotoma (Fig. 6d), consistent with figure 4 that shows the depth of the average chlorophyll fluorescence maximum at the base of the metalimnion in these lakes. Whilst the depth of the chlorophyll fluorescence maximum $\left(\mathrm{z}_{\mathrm{chlFmax}}\right)$ was also mostly near the base of the epilimnion $\left(\mathrm{z}_{\mathrm{SML}}\right)$ in Lake Tarawera, it did occur within the epilimnion (i.e., $\mathrm{z}_{\text {chlFmax }}<\mathrm{z}_{\mathrm{SML}}$ ) on one occasion, in October 2003 (Fig. 7d). In Lake Rotoiti, the 
chlorophyll fluorescence maximum was within the epilimnion $\left(\mathrm{z}_{\mathrm{chlFmax}}<\mathrm{z}_{\mathrm{SML}}\right)$ for more than $50 \%$ of observations (Fig. 6d). In all lakes except Rotoiti, the chlorophyll fluorescence maximum occurred at depths where the irradiance was 1 to $5 \%$ of surface irradiance (Fig. 6e).

There were marked differences in surface concentrations of $\mathrm{PO}_{4}-\mathrm{P}, \mathrm{NO}_{3}-\mathrm{N}$ and $\mathrm{NH}_{4}-\mathrm{N}$, as well as chl $a$ across the four lakes (Fig. 8). Nutrient concentrations in Lake Rotoiti were significantly higher (paired t-test, $\mathrm{p}<0.01$ ) compared with each of the other three lakes. There were no differences in dissolved inorganic nitrogen species between lakes Rotoma and Tarawera, but $\mathrm{PO}_{4}-\mathrm{P}$ in Lake Tarawera was significantly higher $(\mathrm{p}<0.01)$ than in both lakes Rotoma and Taupo. The latter two lakes showed no significant difference $(\mathrm{p}>0.05)$ in $\mathrm{PO}_{4}-\mathrm{P}$. Lake Taupo had very low inorganic nitrogen concentrations and both $\mathrm{NO}_{3}-\mathrm{N}$ and $\mathrm{NH}_{4}-\mathrm{N}$ were significantly lower $(\mathrm{p}<$ 0.01) than in lakes Rotoma and Tarawera. Chlorophyll $a$ concentrations in Lake Rotoiti were significantly higher $(\mathrm{p}<0.01)$, and in Lake Taupo significantly lower ( $\mathrm{p}$ $<0.01)$, than in each of lakes Tarawera and Rotoma, with no significant difference ( $p$ $>0.05)$ between the latter two lakes.

\section{Discussion}

\section{Chlorophyll distribution regimes}

A criterion for DCM formation is that the euphotic depth is below the base of the epilimnion, i.e., $\mathrm{z}_{\mathrm{eu}}>\mathrm{z}_{\mathrm{SML}}$. Since the euphotic depth can be expressed in terms of the light attenuation coefficient, $\mathrm{K}_{\mathrm{d}}$, the critical $\mathrm{K}_{\mathrm{d}}$ value for the formation of a DCM will be:

$$
\mathrm{K}_{\mathrm{d} \text { critical }}=\frac{4.61}{\mathrm{z}_{\mathrm{SML}}}
$$


This equation defines the regime shift between two states in these deep monomictic lakes; a surface-dominated phytoplankton population when $\mathrm{K}_{\mathrm{d}} \geq \mathrm{K}_{\mathrm{d} \text { critical }}$ and a DCM-dominated population when $\mathrm{K}_{\mathrm{d}}<\mathrm{K}_{\mathrm{d} \text { critical. }}$ Deep chlorophyll maxima occurred in lakes Taupo $\left(\mathrm{K}_{\mathrm{d}}=0.09-0.16 \mathrm{~m}^{-1}\right)$, Rotoma $\left(\mathrm{K}_{\mathrm{d}}=0.11-0.20 \mathrm{~m}^{-1}\right)$ and Tarawera $\left(\mathrm{K}_{\mathrm{d}}=0.16-0.27 \mathrm{~m}^{-1}\right)$, while surface chlorophyll maxima (within the epilimnion) occurred in Lake Tarawera (briefly) and Lake Rotoiti $\left(\mathrm{K}_{\mathrm{d}}=0.23-0.73 \mathrm{~m}^{-}\right.$ $\left.{ }^{1}\right)$.

Deep chlorophyll maxima can also be found in shallower dimictic lakes and also at times when the euphotic depth is greater than the epilimnion depth (Fee, 1976). Variations in compensation depths of different algal species (Larson et al., 1987) and isolume penetration depths (i.e., a fixed absolute value of irradiance) at different times of year (Letelier et al., 2004) can also be evaluated relative to surface mixing depths in order to determine potential for DCM formation. Equation 4 may be used to examine concentrations of nutrients or chl $a$ in the surface mixed layer that may be necessary for the formation or destruction maintain or restore the DCM. For example, using a chlorophyll-specific absorption coefficient for Lake Taupo of $0.027 \mathrm{~m}^{2}(\mathrm{mg}$ chl $a)^{-1}$ (Belzile et al., 2004), an increase in average chl $a$ to c. $4 \mu \mathrm{g} \mathrm{L}^{-1}$ in this lake would increase $\mathrm{K}_{\mathrm{d}}$ from its current average value of $0.12 \mathrm{~m}^{-1}$ to the critical value of $0.23 \mathrm{~m}^{-1}$, and hence could shift the summer profile in the lake from a DCM to a surface layer maximum.

Correlation coefficients were low $(\mathrm{R}<0.4)$ between concentrations of nutrients $\left(\mathrm{PO}_{4}-\mathrm{P}\right.$ or $\left.\mathrm{NO}_{3}-\mathrm{N}+\mathrm{NH}_{4}-\mathrm{N}\right)$ and chl $a$ in individual lakes and amongst the four lakes, but there was a consistent pattern of lakes with highest range in nutrient concentrations also having the highest range in chl $a$ concentrations. We attribute the observed low correlation coefficients between concentrations of nutrients and chl $a$ as 
largely due to temporal separations between nutrient availability and phytoplankton uptake and growth.

Our analysis neglects the feedback of changes in water clarity on thermodynamics that may help to reinforce the DCM state because the thermocline can be expected to migrate upward as water clarity is reduced (Kumagai et al., 2000). Amongst our study lakes, however, Rotoiti provides an end-member where, despite the relatively shallow thermocline, the lower water clarity prevents the formation of a DCM and the chlorophyll maximum occurs at higher levels of irradiance than in the three other study lakes. Eutrophication of several of the Rotorua lakes (Hamilton, 2005) is of particular concern due to its potential to reduce water clarity and induce dominance of surface-dominated phytoplankton communities, particularly buoyancy regulating cyanobacteria.

Whilst the occurrence of seasonal thermal density stratification and presence of a metalimnion are prerequisites for existence of a DCM, our study shows that the depth of light penetration most critically influences the depth of this community. We observed the DCM depth to track most closely with depths where the irradiance was $1-2 \%$ of surface values, consistent with observations for shallower dimictic lakes (Fee, 1976; Williamson et al., 1996) as well as other monomictic lakes (Pérez et al., 2007). Isolume values (cf. Letelier et al., 2004) may better align with compensation irradiances (Tett et al., 2002), however, and improve predictions of the depth of the fluorescence maximum over estimates based solely on euphotic depth, particularly in individual lakes.

In eutrophic Lake Rotoiti, which has relatively low transparency, the chlorophyll maximum formed within the epilimnion. In contrast, in hightransparency lakes with lower nutrient concentrations, a relatively shallow surface 
mixed layer formed in the early stages of stratification, and fluorescence maxima were mostly in the lower part of the metalimnion or sometimes extended into the hypolimnion (e.g., Taupo and Rotoma). As the mixed layer deepened over the course of the seasonal stratification cycle, the thermocline depth became more closely aligned with the euphotic depth, and the depth of the DCM also began to more closely approximate the thermocline depth. A critical period may follow the summer solstice, when the thermocline deepens while isolumes become shallower. For Lake Tarawera, there appeared to be a brief switch to a surface chlorophyll fluorescence peak in October (spring) 2003. In Lake Tarawera, relatively small changes in phytoplankton biomass (e.g., from additional nutrient inputs) or inorganic turbidity (e.g., from tributary stormflows) could reduce irradiance sufficiently to result in a surface chlorophyll maximum. Relatively small increases in nutrients that lead to increased phytoplankton biomass could decrease transparency and shift the chlorophyll maximum up the water column in a non-linear transition at a critical threshold when the DCM population is below its compensation depth. For example, HowardWilliams et al. (1986) noted that in deep Lake Waikaremoana $\left(z_{\max }=248 m\right)$, also in central North Island (NZ), the DCM could readily be disrupted by small changes in water clarity arising mostly from inorganic turbidity. Changes in CDOM or non-algal material, as well as phytoplankton, should therefore also be included amongst consideration of the potential influences on chlorophyll distributions.

\section{Seasonal variations in chlorophyll profiles}

The seasonal pattern of depth integrated chlorophyll fluorescence through the water column was similar across all four lakes. Winter mixis constitutes a seasonal reset of 
phytoplankton populations after which a surface chlorophyll maximum or a DCM is likely to re-establish dependent mostly on water clarity.

Chlorophyll concentrations in the surface mixed layer can increase through entrainment of phytoplankton from the DCM into surface waters in shallower lakes, as this layer deepens seasonally (Fee, 1976). However, the relative contribution of the DCM to depth integrated chlorophyll is likely to be smaller in the four deep lakes of our study (Fig. 4) and there were large increases in depth integrated chlorophyll in autumn/winter. We attribute the increases in chlorophyll to increased nutrient availability with deepening of the surface mixed layer, as well as reduced sedimentation losses, despite sub-optimal water temperature and irradiance. As noted by Marshall and Peters (1989), increasing trophic status across lakes may actually reinforce seasonality, and in mesotrophic Lake Rotoiti there was still a strong seasonal bias of depth-integrated fluorescence towards winter. Our results also confirm the previous observations of highest depth integrated phytoplankton biomass during winter in lakes Taupo and Rotoiti (Vincent 1983; Vincent et al., 1984a).

The depth-increasing profile observed in two of the study lakes appears to be transient and is likely associated with rapid sedimentation of diatom populations (e.g. Aulacoseira granulata, Asterionella formosa) at rates of up to $10 \mathrm{~m} \mathrm{~d}^{-1}$ at the onset of stratification (Viner and White, 1987). This pattern may occur when the epilimnion is too shallow for the population to 'outgrow' sedimentation losses (Huisman and Sommeijer, 2002; O'Brien et al., 2003). Many of the dominant winter diatom species persist in the DCM during summer stratification, as noted previously in lakes Taupo and Tarawera (Ryan et al., 2005; Ryan et al., 2006). These species are evidently able to exploit a niche where there is adequate irradiance and nutrient supply, and thus can 'outgrow' the cumulative losses from metabolism, sedimentation, grazing and lysis. 
By contrast, cyanobacteria (e.g. Microcystis aeruginosa and Anabaena circinalis) become increasingly dominant during stratification (Ryan et al., 2006), until the surface mixed layer begins to deepen substantially preceding winter turnover. Because these populations can regulate buoyancy and form surface blooms, they tend to exhibit high levels of horizontal variability compared with DCM populations (Ryan et al., 2005), with potential for massive accumulations on leeward shores (Reynolds, 1997).

The greater duration of continuous stratification in the monomictic lakes of our study compared with dimictic or polymictic lakes, provides a longer window of time in which phytoplankton populations can 'equilibrate' to the prevailing environmental conditions, with limited replenishment of nutrients from depth. The forces governing the selection, dynamics and diversity of phytoplankton are therefore likely to be more clearly elucidated in these monomictic lakes (cf. Tilman, 1996), particularly in oligotrophic systems subject to severe nutrient limitation. Under a regime of warming climate, the lakes of this study may provide a valuable comparative example of changes that may be expected in phytoplankton succession and vertical distribution with increasing duration of stratification or when a dimictic lake becomes monomictic.

\section{Acknowledgments}

This study was funded through the Foundation of Research, Science and Technology (Contract UOWX0505) and the University of Waikato Lakes Chair supported by Environment Bay of Plenty. KO'B's participation in this project was supported by research grants from the School of Engineering, University of Queensland. We 
acknowledge the assistance of Dennis Trolle in discussions on this manuscript, and George Ganf, Warwick Vincent and Emanuel Boss for reviews.

\section{References}

Abbott, M. R., K. L. Denman, T. M. Powell, P. J. Richerson, R. C. Richards and C. R. Goldman, 1984. Mixing and the dynamics of the deep chlorophyll maximum in Lake Tahoe. Limnology and Oceanography 29: 862-878.

Arar, E. J. and J. B. Collins, 1992. In-vitro determination of chlorophyll-a and pheophytin-a in marine and freshwater algae by fluorescence. Method 445.0, National Exposure Laboratory, Office of Research and Development, US Environmental Protection Agency, Washington, DC.

Bayley, S. E., I. F. Creed, G. Z. Sass and A. S. Wong, 2007. Frequent regime shifts in shallow lakes on the Boreal Plain: Alternative "unstable" states? Limnology and Oceanography 52: 2002-2012.

Belzile, C., W. F. Vincent, C. Howard-Williams, I. Hawes, M. R. James, M. Kumagai and C. S. Roesler 2004. Relationships between spectral optical properties and optically active substances in a clear oligotrophic lake. Water Resources Research 40: 1-12.

Carpenter, S. R., 2003. Regime Shifts in Lake Ecosystems: Pattern and Variation. Excellence in Ecology Series, Vol. 15, Ecology Institute, Olendorf/Luhe, Germany.

Cassie, V., 1978. Seasonal changes in phytoplankton densities in four North Island lakes, 1973-74. New Zealand Journal of Marine and Freshwater Research 12: $153-166$. 
Clegg, M. R., S. C. Maberly and R. I. Jones, 2007. Behavioral response as a predictor of seasonal depth distribution and vertical niche separation in freshwater phytoplanktonic flagellates. Limnology and Oceanography 52: 441-455.

Condie, S. A., 1999. Settling regimes for non-motile particles in stratified waters. Deep Sea Research I 46: 681-699.

Davey, M. C. and S. I. Heaney, 1989. The control of sub-surface maxima of diatoms in a stratified lake by physical, chemical and biological factors. Journal of Plankton Research 11: 1185-1199.

Fee, E. J., 1976. The vertical and seasonal distribution of chlorophyll in lakes of the Experimental Lakes Area, northwest Ontario: implications for primary productivity estimates. Limnology and Oceanography 21: 767-783.

Fennel, K. And E. Boss, 2003. Subsurface maxima of phytoplankton and chlorophyll: Steady-state solutions from a simple model. Limnology and Oceanography 48: $1521-1534$.

Hamilton, D. P., 2005. Land use impacts on nutrient export in the Central Volcanic Plateau, North Island. New Zealand Journal of Forestry 49: 27-31.

Hamilton, D. P., I. Hawes and M. M. Gibbs, 2005. Climatic shifts and water quality response in North Island lakes, New Zealand. Verhandlungen Internationale Vereinigung für Theoretische und Angewandte Limnologie 29: 1821-1824. Howard-Williams, C., K. Law, C. L. Vincent, J. Davies and W. F. Vincent, 1986. Limnology of Lake Waikaremoana with special reference to littoral and pelagic primary producers. New Zealand Journal of Marine and Freshwater Research 20: $583-597$.

Huisman, J., and B. Sommeijer, 2002. Maximal sustainable sinking velocity of phytoplankton. Marine Ecology Progress Series 244: 39-48. 
Huisman, J., N. N. P. Thi, D. M. Karl and B. Sommeijer, B., 2006. Reduced mixing generates oscillations and chaos in the oceanic deep chlorophyll maximum. Nature 439: 322-325.

Kumagai, M., S. Nakano, C. Jiao, K. Hayakawa, S. Tsujimura, T. Nakajima, J.-J. Frenette and A. Queseda, 2000. Effect of cyanobacterial blooms on thermal stratification. Limnology 1: 191-195.

Larson, D. W., C. N. Dahm and N. S. Geiger, 1987. Vertical partitioning of the phytoplankton assemblage in ultraoligotrophic Crater Lake, Oregon, U.S.A. Freshwater Biology 18: 429-442.

Letelier, R. M., D. M. Karl, M. R. Abbott and R. R. Bidigare, 2004. Light driven seasonal patterns of chlorophyll and nitrate in the lower euphotic zone of the North Pacific Subtropical Gyre. Limnology and Oceanography 29: 508-519. MacIntyre, S., A. L. Aldridge and C. G. Gotschal, 1995. Accumulation of marine snow at density discontinuities in the water column. Limnology and Oceanography 40: 449-468.

Marshall, C. T. and R. H. Peters, 1989. General patterns in the seasonal development of chlorophyll $a$ for temperate lakes. Limnology and Oceanography 34: 856867.

O’Brien, K. R., G. N. Ivey, D. P. Hamilton, A. M. Waite and P. M. Visser, 2003. Simple mixing criteria for the growth of negatively buoyant phytoplankton. Limnology and Oceanography 48: 1326-1337.

Pérez, G., C. Queimalinos, E. Balseiro and B. Modenutti, 2007. Phytoplankton absorption spectra along the water column in deep North Patagonian Andean lakes (Argentina). Limnologica - Ecology and Management of Inland Waters 37: 3-16. 
Reynolds, C. S., 1997. Vegetation Processes in the Pelagic: A Model for Ecosystem Theory. Excellence in Ecology Series, Vol. 9, Ecology Institute, Olendorf/Luhe, Germany.

Ryan, E. F., D. P. Hamilton, J. A. Hall and U. V. Cassie-Cooper, 2005. Lake phytoplankton composition and biomass along horizontal and vertical gradients. Verhandlungen Internationale Vereinigung Limnologie 29: 1033-1036.

Ryan, E. F., I. C. Duggan, D. P. Hamilton and D. Burger, 2006. Phytoplankton community composition in North Island lakes of New Zealand: is trophic state, mixing, or light climate more important? New Zealand Journal of Marine and Freshwater Research 40: 389-398.

Sackmann, B. S., M. J. Perry and C. C. Eriksen, 2008. Seaglider observations of variability in daytime fluorescence quenching of chlorophyll-a in Northeastern Pacific coastal waters. Biogeosciences Discussions 5: 2839-2865.

Sherman, B. S., I. T. Webster, G. T. Jones and R. L. Oliver, 1998. Transitions between Aulacoseira and Anabaena dominance in a turbid river weir pool. Limnology and Oceanography 43: 1902-1915.

Spigel, R. H. And J. Imberger, 1987. A review of mixing processes relevant to phytoplankton dynamics in lakes. New Zealand Journal of Marine and Freshwater Research 21: 392-405.

Steele, J. H., 1964. A study of production in the Gulf of Mexico. Journal of Marine Research 22: 211-222.

Tett, P., J. Arístegui, D. Barton, G. Basterretxea, J. D. De Armas, J. E. Escánez, S. H. León, L. M. Lorenzo and N. Montero, 2002. Steady-state DCM dynamics in Canaries waters. Deep-Sea Research II 49: 3543-3559. 
Tilman, D., 1996. Biodiversity: population versus ecosystem stability. Ecology 77: $350-363$.

Vincent, W. F., 1983. Phytoplankton production and winter mixing: contrasting effects in two oligotrophic lakes. Journal of Ecology 71: 1-20.

Vincent, W. F., M. M. Gibbs and S. J. Dryden, 1984a. Accelerated eutrophication in a New Zealand lake: Lake Rotoiti, central North Island. New Zealand Journal of Marine and Freshwater Research 18: 431-440.

Vincent, W. F., P. J. Neale and P. J. Richerson, 1984b. Photoinhibition: algal responses to bright light during diel stratification and mixing in a tropical alpine lake. Journal of Phycology 20: 201-211.

Viner, A. W. and E. White, 1987. Phytoplankton growth. In: A. B. Viner (ed.), Inland Waters of New Zealand, Department of Scientific Information and Research Bulletin No. 241, Wellington, N.Z., pp. 191-224.

Walsby, A. E. and F. Schanz, 2002. Light-dependent growth rate determines changes in the population of Planktothrix rubescens over the annual cycle in Lake Zurich, Switzerland. New Phytologist 154: 671-687.

Williamson, C. E., R. W. Sanders, R. E. Moeller and P. L. Stutzman, 1996. Utilization of subsurface food resources for zooplankton reproduction: Implications for diel vertical migration theory. Limnology and Oceanography 41: 224-233.

Wurtsbaugh, W. A., H. P. Gross, P. Budy and C. Luecke, 2001. Effects of epilimnetic versus metalimnetic fertilization on the phytoplankton and periphyton of a mountain lake with a deep chlorophyll maxima. Canadian Journal of Fisheries and Aquatic Sciences 58: 2156-2166. 


\section{List of Tables}

Table 1. Maximum depth, volume, catchment area, annual range of surface and bottom temperatures, and trophic state based on annual mean nutrient and chlorophyll levels of the four study lakes. Temperature data relate to the period of this study (2003-6) and chlorophyll $a$ data are summer mean values (2003-6).

\begin{tabular}{lccccccc}
\hline Lake & $\begin{array}{c}\text { Max. } \\
\text { depth } \\
(\mathrm{m})\end{array}$ & $\begin{array}{c}\text { Area } \\
\left(\mathrm{km}^{2}\right)\end{array}$ & $\begin{array}{c}\text { Volume } \\
\left(\mathrm{km}^{3}\right)\end{array}$ & $\begin{array}{c}\text { Catchment } \\
\text { area } \\
\left(\mathrm{km}^{2}\right)\end{array}$ & $\begin{array}{c}\text { Surface } \\
\text { temperature } \\
\left({ }^{\circ} \mathrm{C}\right)\end{array}$ & $\begin{array}{c}\text { Bottom } \\
\text { temperature } \\
\left({ }^{\circ} \mathrm{C}\right)\end{array}$ & $\begin{array}{c}\text { Chl } a \\
\left(\mathrm{mg} \mathrm{m}^{-3}\right)\end{array}$ \\
\hline Taupo & 164 & 606 & 56 & 3,289 & $11.1-20.6$ & $10.6-11.1$ & 0.75 \\
Rotoma & 83 & 11.1 & 0.43 & 34 & $11.2-22.1$ & $10.7-12.6$ & 0.93 \\
Tarawera & 88 & 41.4 & 2.3 & 150 & $11.0-21.7$ & $10.9-11.7$ & 1.26 \\
Rotoiti & 124 & 34.4 & 1.0 & 578 & $11.1-22.0$ & $10.7-13.5$ & 8.70 \\
\hline
\end{tabular}


Table 2. Annual sequence of changes in the four fluorescence distribution modes (CFM - chlorophyll fluorescence maximum, SML - surface mixed layer chlorophyll fluorescence maximum, Uniform, and Bottom Layer - increasing chlorophyll fluorescence with depth) for each lake. Black squares indicate three observations, dark gray squares indicate two observations, and light gray squares indicate a single observation in each month (as also numbered in squares).

\begin{tabular}{|c|c|c|c|c|c|c|c|c|c|c|c|c|}
\hline & Jan & Feb & Mar & Apr & May & Jun & Jul & Aug & Sep & Oct & Nov & Dec \\
\hline \multicolumn{13}{|l|}{ Lake Taupo } \\
\hline CFM & 1 & 2 & 2 & 1 & & & & & & & & 1 \\
\hline \multicolumn{13}{|l|}{ SML } \\
\hline Uniform & & & & & & & 1 & & & & & \\
\hline \multicolumn{13}{|l|}{ Bottom Layer } \\
\hline \multicolumn{13}{|l|}{ Lake Rotoma } \\
\hline CFM & 2 & 2 & 1 & 1 & & & & & & & & 1 \\
\hline SML & & & 1 & 1 & 1 & 2 & & & & & & \\
\hline Uniform & & & & & & & 3 & & & & 1 & \\
\hline Bottom Layer & & & & & & & & 2 & 1 & 1 & & \\
\hline \multicolumn{13}{|c|}{ Lake Tarawera } \\
\hline CFM & 2 & 1 & & 2 & & & & & & 2 & 2 & 2 \\
\hline SML & & 1 & 1 & 2 & 2 & 2 & & & & & & \\
\hline Uniform & & & & & & & 1 & 2 & 2 & & & \\
\hline \multicolumn{13}{|l|}{ Bottom Layer } \\
\hline \multicolumn{13}{|l|}{ Lake Rotoiti } \\
\hline CFM & 2 & 2 & & 1 & & & & & 1 & 1 & & \\
\hline SML & & & 1 & 2 & 2 & & & & & & & 1 \\
\hline Uniform & & & & & & 2 & 3 & 1 & 1 & 1 & & \\
\hline Bottom Layer & & & & & & & & 1 & 1 & & 1 & \\
\hline
\end{tabular}




\section{Figure legends}

Figure 1. Location of the four study lakes in North Island, New Zealand, also showing other lakes of the Rotorua district. Dashed line shows Biofish transect, arrows denote the end of the transect, and shaded circle shows the central sampling station in each lake.

Figure 2. Transects of in vivo fluorescence approximated to chl $a\left(\mu \mathrm{g} \mathrm{L}^{-1}\right)$, including depth profiles for (a) Lake Taupo, 21 January 2005; (b) Lake Rotoma, 9 February 2005; (c) Lake Tarawera, 2 December 2004; (d) Lake Rotoiti, 20 December 2004. The transect depth follows the dashed line and the path and direction are indicated in figure 1 with the central lake stations located at approximately $15,3.3,5$ and $11 \mathrm{~km}$, respectively, along the transect. Areas not filled represent insufficient data for interpolation.

Figure 3. Vertical fluorescence profiles approximated to chl $a\left(\mu \mathrm{g} \mathrm{L}^{-1}\right)$, euphotic depth (dashed line) and metalimnetic depth range (shaded area) at the central sampling station (see Fig. 1) in Lake Taupo in March, April, June and July 2006, Lake Rotoma in January, June, July and September 2006, Lake Tarawera in November 2003, February, April and August 2004, and Lake Rotoiti in January, April, June and September 2006.

Figure 4. Vertical distributions of chlorophyll fluorescence normalized by the depthaveraged fluorescence, and averaged for the four selected modes of distribution (Chlorophyll Fluorescence Maximum, Surface Mixed Layer, Uniform and Bottom 
Layer) at the central sampling station (see Fig. 1) of the four lakes. Each column represents a different fluorescence distribution mode, and each row represents a different lake, as labelled. Shaded area indicates metalimnion, dotted line indicates euphotic depth. See figure 5 for the number of profiles that were averaged for each distribution mode.

Figure 5. Thermocline depth and depth-averaged fluorescence at the central sampling station (see Fig. 1) for (a) Lake Taupo, December 2004 to July 2006; (b) Lake Rotoma, June 2004 to October 2006; (c) Lake Tarawera, April 2003 to May 2005; (d) Lake Rotoiti, April 2004 to October 2006.

Figure 6. Box plots of (a) the depth of chlorophyll fluorescence maximum $z_{F m a x}$, as defined by a peak exceeding depth-averaged fluorescence by at least $40-50 \%$, and excluding peaks associated with uniform distributions in surface mixed layer, (b) euphotic depth $\mathrm{z}_{\mathrm{eu}},(\mathrm{c})$ depth of epilimnion $\mathrm{z}_{\mathrm{SML}}$, (d) difference between the bottom depth of the epilimnion $\mathrm{z}_{\mathrm{SML}}$, and the depth of the chlorophyll fluorescence maximum $\mathrm{Z}_{\mathrm{chlFmax}},(\mathrm{e})$ percentage of surface irradiance which reaches the depth of the fluorescence maximum and (f) light attenuation coefficient $\mathrm{K}_{\mathrm{d}}$ at the central sampling station (see Fig. 1) for Lake Taupo (December 2004 to July 2006), Lake Rotoma (June 2004 to October 2006), Lake Tarawera (April 2003 to May 2005) and Lake Rotoiti (April 2004 to October 2006). The lower line of the box indicates the first quartile, middle line is the median, and upper line is the third quartile. The whiskers show the extent of the data, and crosses indicate outliers not used in the statistical analysis. 
Figure 7. (a) Depth of chlorophyll fluorescence maximum, $\mathrm{Z}_{\mathrm{Fmax}}$ vs euphotic depth, $\mathrm{Z}_{\mathrm{eu}}\left(\mathrm{z}_{\mathrm{chllFmax}}=-1.6+0.92 \mathrm{z}_{\mathrm{eu}}, \mathrm{p}<0.01 ;\right.$ (b) $\mathrm{z}_{\text {chllFmax }}$ vs depth of epilimnion $\mathrm{z}_{\mathrm{SML}}$; (c) $\mathrm{Z}_{\mathrm{SML}} \mathrm{vs} \mathrm{Z}_{\mathrm{eu}}$ at the central sampling station of each lake (see Fig. 1).

Figure 8. Box plots of (a) chlorophyll $a$, (b) $\mathrm{PO}_{4}-\mathrm{P}$, (c) $\mathrm{NO}_{3}-\mathrm{N}$ and (d) $\mathrm{NH}_{4}-\mathrm{N}$ concentrations $\left(\mu \mathrm{g} \mathrm{L}^{-1}\right)$ at the central sampling station (see Fig. 1$)$ at the surface $(0-10$ $\mathrm{m}$ ) of Lake Taupo and 0-17 $\mathrm{m}$ for the other three lakes, for the period June 2003 to June 2005. The lower line of the box indicates first quartile, middle line is median, and upper line is third quartile. The whiskers show the extent of the data, and crosses indicate outliers not included in statistical summaries. 


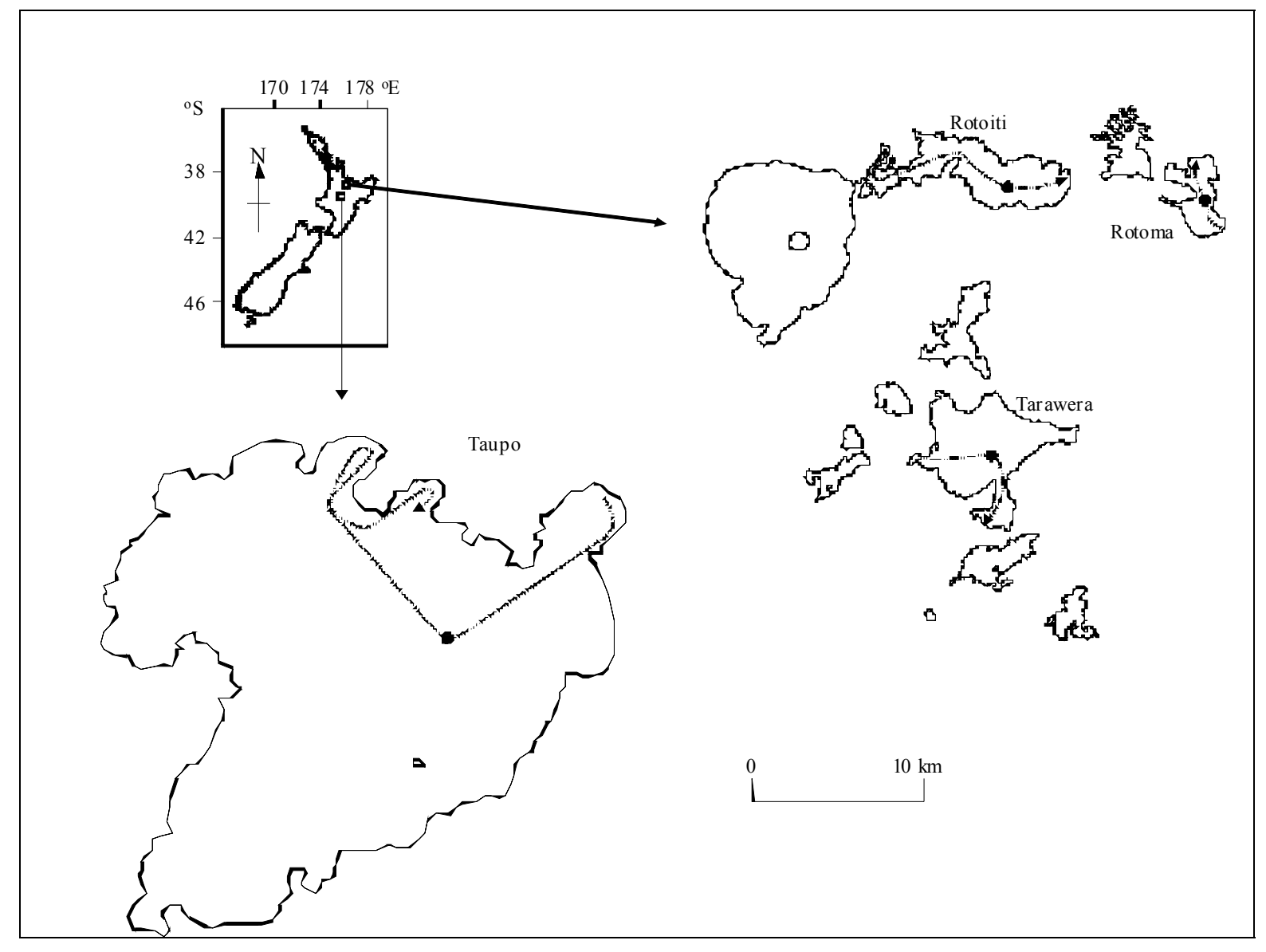

Fig. 1 

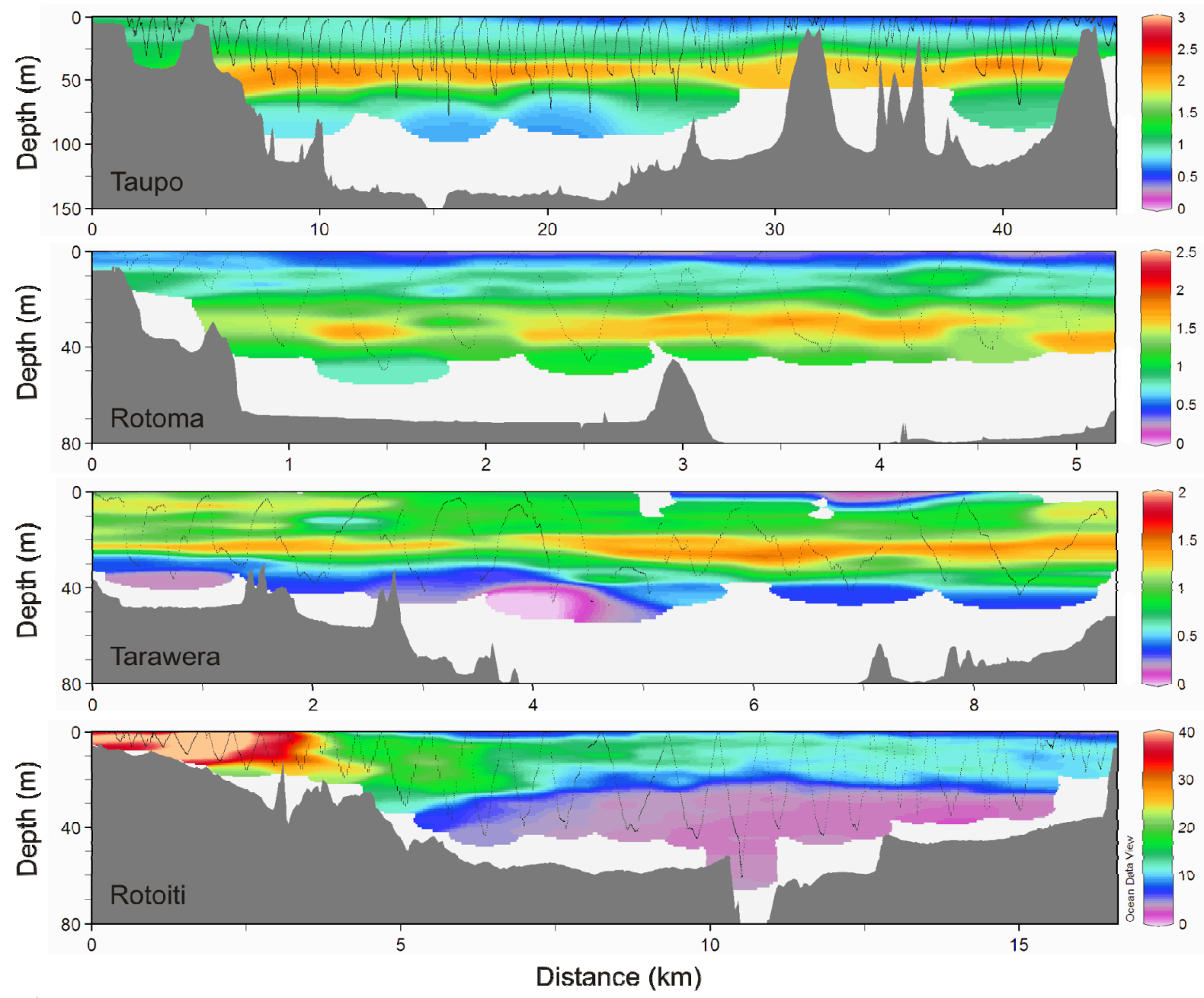

Fig. 2 

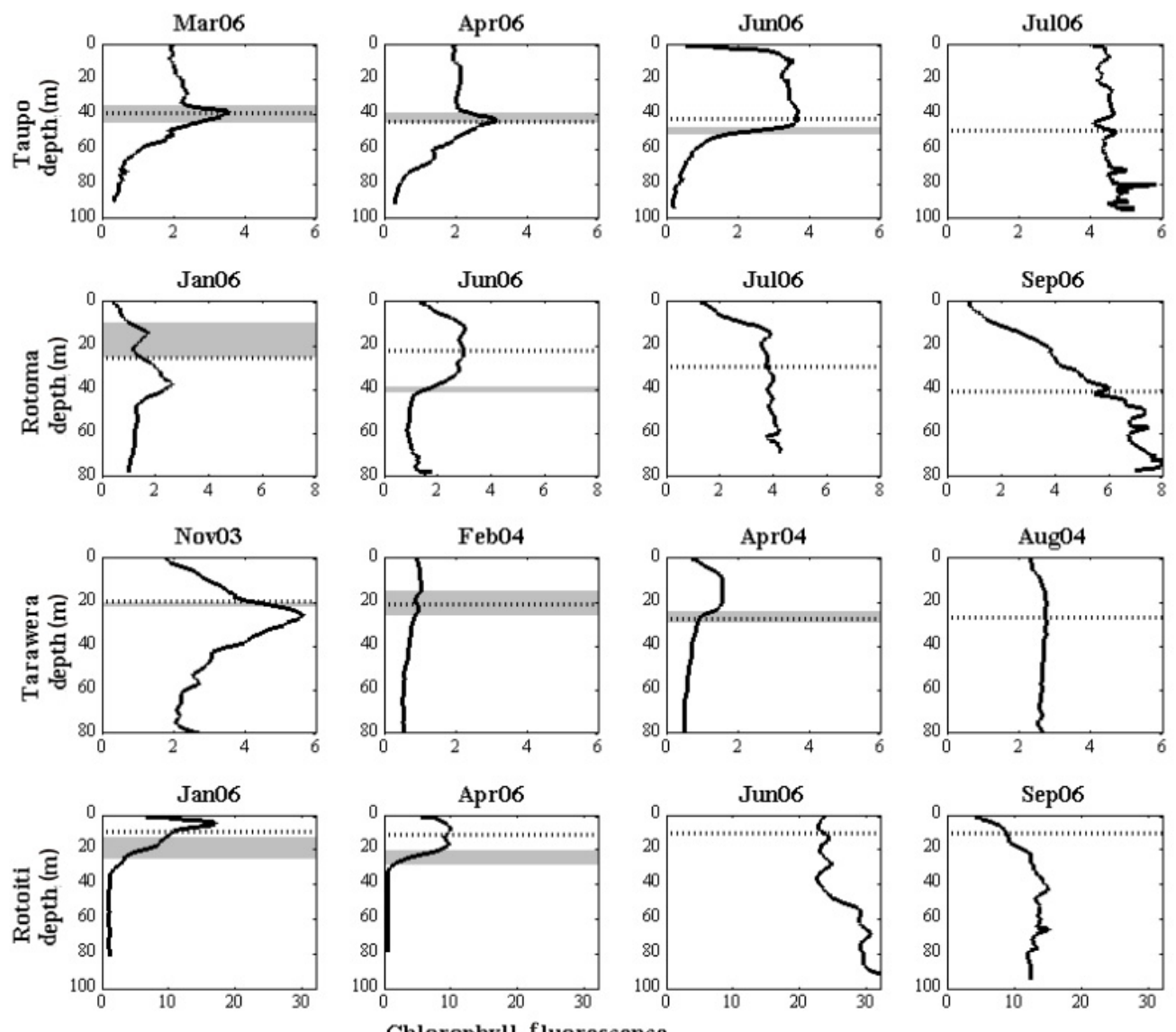

Fig. 3 

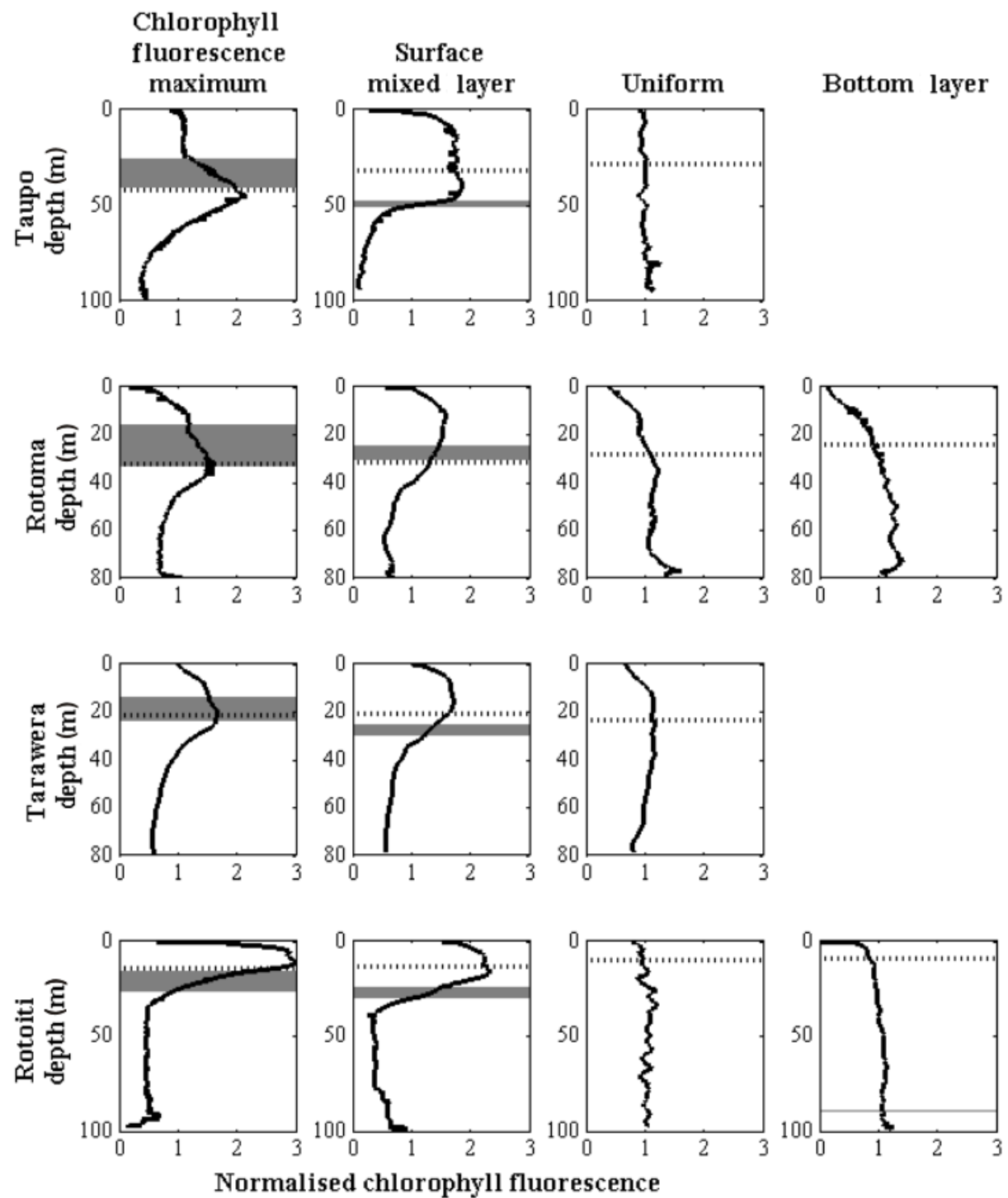

Fig. 4 

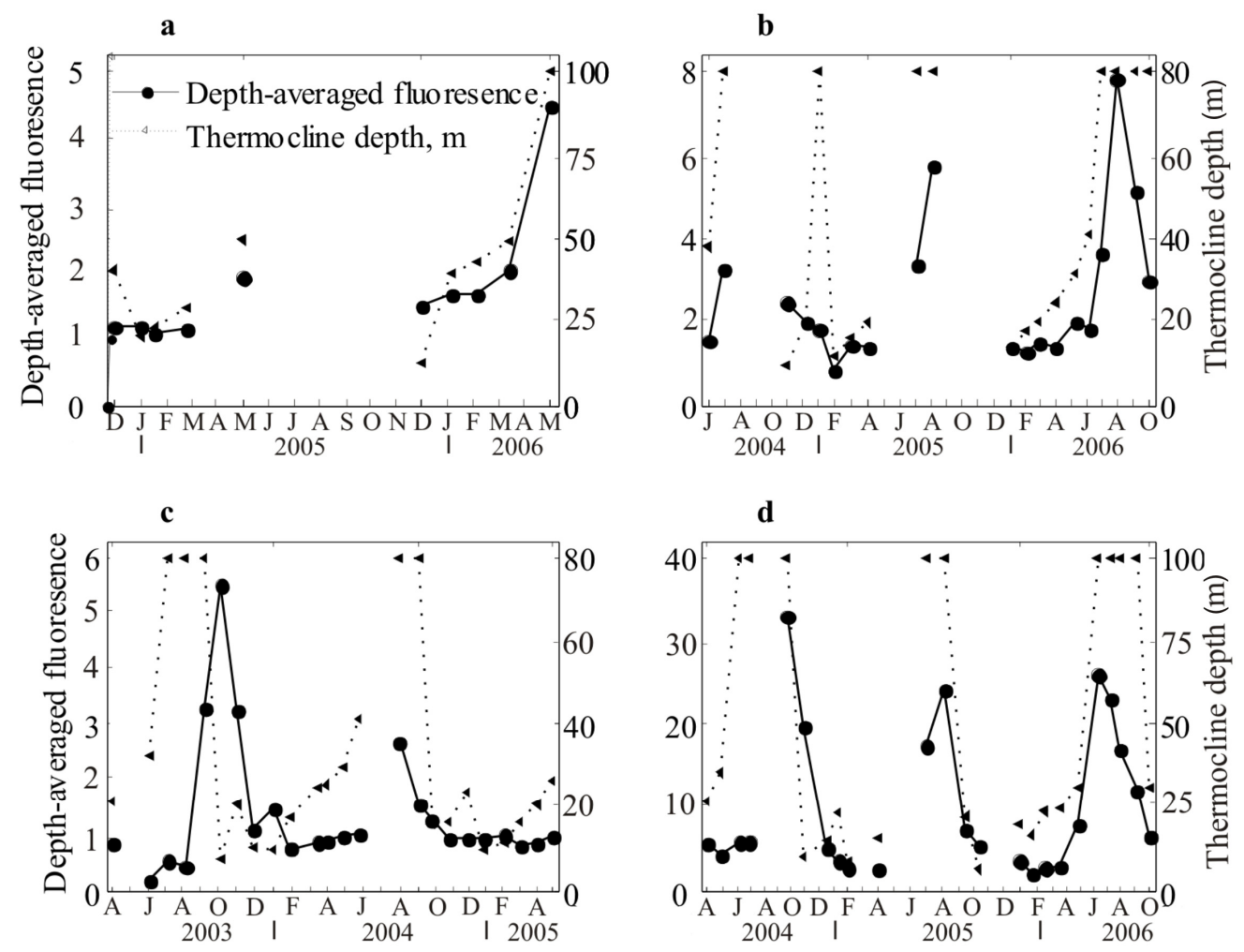

Fig. 5 

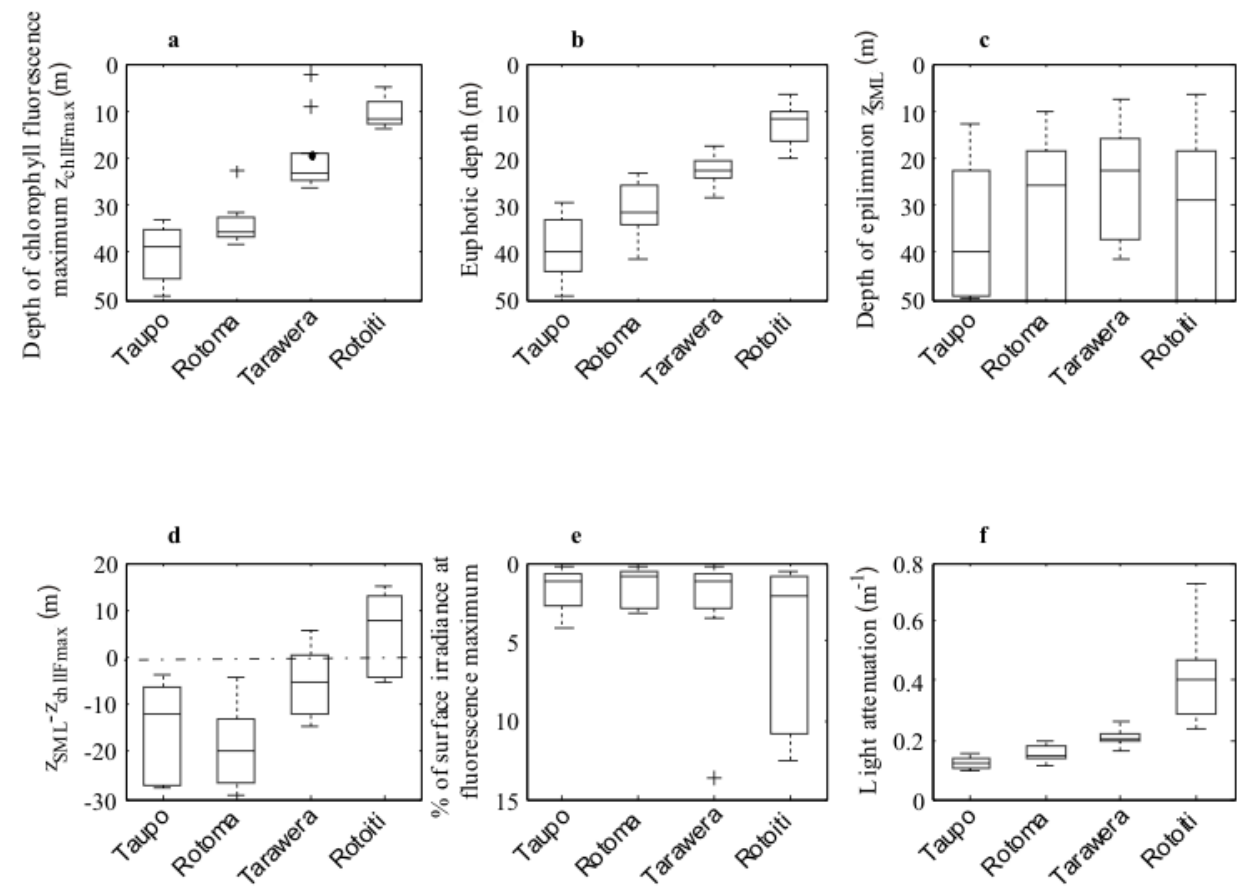

Fig. 6 

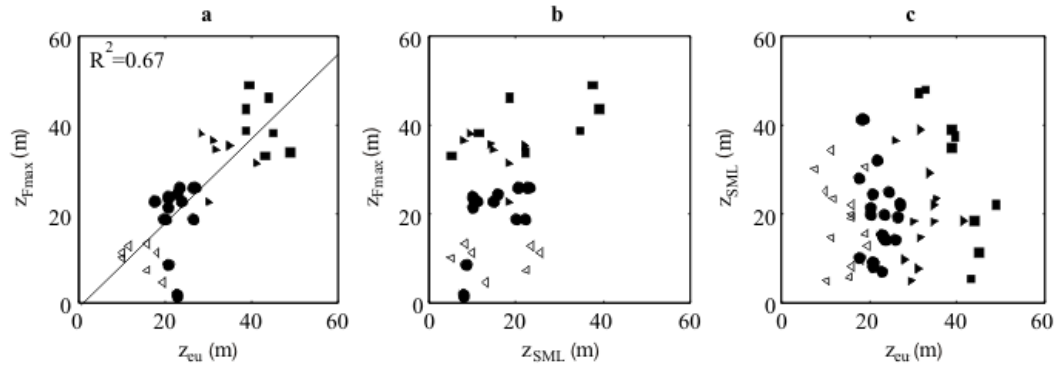

$$
\begin{aligned}
& \text { - Taupo } \\
& \text { - Tarawera } \\
& \hline
\end{aligned}
$$

Fig. 7 
a

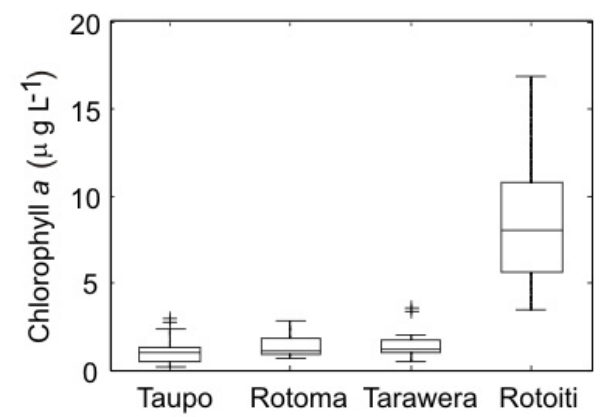

c

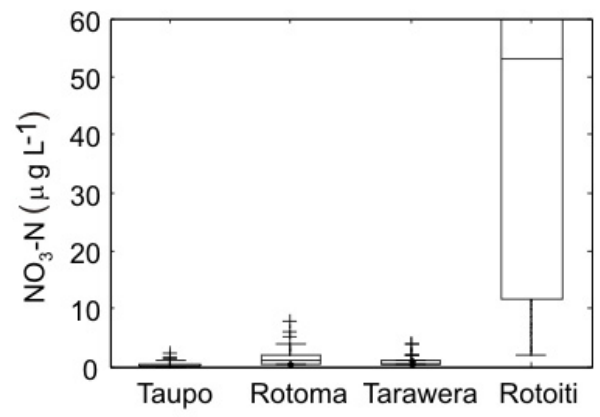

b

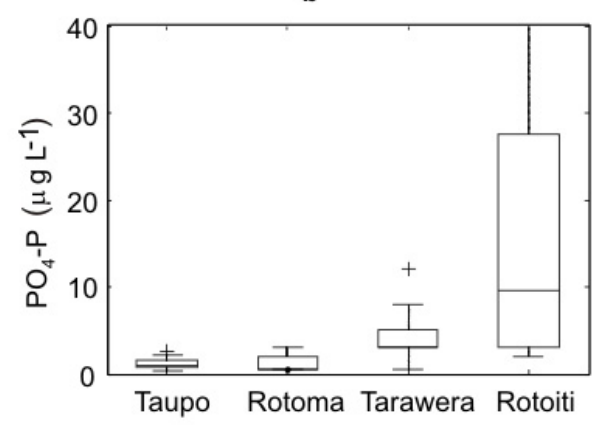

d

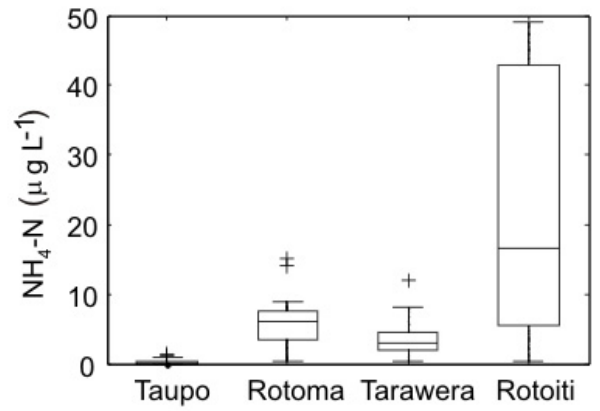

Fig. 8 